\title{
OA12.01. Analysis of FDA mandated dietary supplement adverse event reports (AER) 2008-2009
}

\author{
M Hardy ${ }^{1 *}$, S Stumpf ${ }^{1}$, M Zimmerman $^{2}$, C Carr $^{1}$ \\ From International Research Congress on Integrative Medicine and Health 2012 \\ Portland, Oregon, USA. 15-18 May 2012
}

\section{Purpose}

Safety of dietary supplements has been an area of concern for regulators, the health care community and consumers. The ability of the FDA to assess validity of these concerns has been hampered by small numbers of voluntary AE reports. In 2006 Congress mandated all serious adverse events be reported by dietary supplement manufacturers. We present the first systematic analysis of the initial two years of reports.

\section{Methods}

We obtained AER's for 2008 and 2009 from the FDA $(n=2,288)$. Data were abstracted by a single reviewer, confirmed by at least one other, entered into a standard excel sheet, and analyzed using SPSS. Non-parametric tests of significance were also applied.

\section{Results}

In preliminary results, manufacturers accounted for $57.8 \%$ of all reports, consumers $29.6 \%$ and health care professionals $9.7 \%$. $61.8 \%$ of subjects were female. The most commonly reported dietary ingredients were combination products (33.5\%), vitamin/mineral (19\%), and plant or isolated plant constituent (15.8\%). 297 reports included multiple products. Fifty-five percent of reports included the label or label information. The most common adverse outcome was hospitalization (750, 32.8\%). Thirty-one deaths were reported (1.4\% total reports), 56 episodes of disability (2.4\%), 233 life-threatening complications (10.2\%), and 943 other serious adverse events (41.2\%). A detailed assessment of deaths, hospitalizations and life threatening complications will be presented. No single product type or ingredient was significantly associated with death. Attempts to apply the WHO-UMC causality assessment system yielded limited results and

${ }^{1}$ Simms/Mann-UCLA Center for Integrative Oncology, Los Angeles, USA Full list of author information is available at the end of the article would be improved with the collection of more sufficient data. A cluster of serious adverse events involving a single exercise enhancement product was identified.

\section{Conclusion}

Mandated reporting has increased manufacturer reports but missing data limits analysis. Preliminary results do not suggest a wide spread problem with dietary supplement safety. This analysis did identify a cluster of cases representing a potential public health concern. Directions for future research will be discussed.

\section{Author details}

${ }^{1}$ Simms/Mann-UCLA Center for Integrative Oncology, Los Angeles, USA.

${ }^{2}$ American Herbal Products Association, Washington D.C., USA.

Published: 12 June 2012

doi:10.1186/1472-6882-12-S1-045

Cite this article as: Hardy et al:: OA12.01. Analysis of FDA mandated dietary supplement adverse event reports (AER) 2008-2009. BMC

Complementary and Alternative Medicine 2012 12(Suppl 1):045.

Submit your next manuscript to BioMed Central and take full advantage of:

- Convenient online submission

- Thorough peer review

- No space constraints or color figure charges

- Immediate publication on acceptance

- Inclusion in PubMed, CAS, Scopus and Google Scholar

- Research which is freely available for redistribution

\section{Biomed Central}

(c) 2012 Hardy et al; licensee BioMed Central Ltd. This is an Open Access article distributed under the terms of the Creative Commons Attribution License (http://creativecommons.org/licenses/by/2.0), which permits unrestricted use, distribution, and reproduction in any medium, provided the original work is properly cited. 